\title{
sciendo
}

\section{Institutions, trust and the high level of innovativeness in the Scandinavian countries}

\author{
Gabriela Misiura $^{\mathrm{a}}$, Małgorzata Rozkwitalska ${ }^{\mathrm{b}}$ \\ ${ }^{a}$ WSB University in Gdańsk, gabriela.misiura@gmail.com \\ ${ }^{b}$ WSB University in Gdańsk, mrozkwitalska@wsb.gda.pl
}

(C) 2019 Gabriela Misiura, Matgorzata Rozkwitalska. This is an open access article distributed under the Creative Commons Attribution-NonCommercial-NoDerivs license (http://creativecommons.org/licenses/by-nc-nd/3.0/

DOI 10.2478/WSBJBF-2019-0005

\begin{abstract}
The aim of this study was to show the relationship between the level of the confidence indicator and the innovation of the economies of individual Scandinavian countries in the context of the new institutional economy (NEI). Literature studies and analysis of available results of social research indicate the importance of formal and informal institutions in Denmark, Sweden, Norway and Finland in making these countries world leaders in innovation.
\end{abstract}

Key words: New Institutional Economy, NEI, confidence index, innovativeness of Scandinavian countries, world leader in innovation, Scandinavian innovations.

1

\section{Introduction}

Relatively small in terms of their populations, the Scandinavian countries are unquestionable leaders of innovation not only in European but also global rankings. Innovation refers to products, sale organisation systems (IKEA and its self-assembly furniture) methods for work organisation and human resources management in companies (flat structure, management by values, work-life balance), and methods applied in expansion to foreign markets (the Uppsala model). It is in Scandinavia that products such as safety belts, matches, chewing gum, zippers (Sweden), Lego blocks, hydrogen tablets (Denmark), cheese knives, baby high chairs, ski (Norway), Molotov cocktails, ice skates, heart rate meters, the SMS system, the Linux operational system and the Angry Birds game (Finland) were designed.

The aim of the article is to present the role of institutions and trust in relation to innovation of the Scandinavian countries. This research has been carried out using a method involving the analysis of current documents and a review of literature. Denmark, Finland, Iceland, Norway and Sweden were the focus of this study based on historical statistical data describing such phenomena as innovation and trust. Polish and foreign scientific literature were also referred in the present study. It should be emphasized that considering the Scandinavian 
countries, the question of innovation has been scarcely studied in Polish literature, especially in the context of the New Institutional Economics (NIE).

In the first part of the article, formal and informal institutions are discussed from the perspective of NIE. In the second part of the article, the notion of trust is presented with the indication of its place in the NIE, along with its significance for innovation of the economies of the Scandinavian countries. The third part of the article presents a discussion on the notion and the status of innovation in the Scandinavian countries. The fourth part provides an analysis of some dependencies observed between the confidence indicators reported in the Scandinavian countries and the innovation levels of their economies.

\section{$2 \quad$ Formal and informal institutions in new institutional economics}

In his The Theory of the Leisure Class, Thorstein Veblen, who is considered to be the creator of institutional economics, presents a theory opposite to neoclassicism, which was very common at that time. He assumes people as culture-conditioned beings whose actions are determined by culture and environment in which they to grow up. Decisions taken by the individuals are adjusted to the requirements of that environment and the established methods of action, which form the framework for the functioning are defined by Veblen as institutions. In other words, he claims that institutions form the basis for human behaviour [Chotkowski, 2010, p. 101]. The representatives of NIE present an opposite thesis, according to which human behaviour forms institutions [Woźniak-Jęchorek, 2014, p. 397]. One of the key figures in NIE, Douglas North, claims that "institutions are the game principles in the society and they come as limitations developed by people to form political, economic and social interactions. They include both informal limitations, namely sanctions, taboos, customs, tradition or principles of behaviour and formal principles, such as constitutions, laws, property rights” [Kuder, 2011, pp. 8586]. Hence, social, political and economic relations in a particular country are affected both by formal institutions that are formed in a conscious and unconscious way and also by informal institutions. Table 1 presents the underlying basis for formal and informal institutions.

Table 1. Formal and informal institutions by Douglas North

\begin{tabular}{|c|c|}
\hline \multicolumn{2}{|c|}{ Institutions by Douglas North } \\
\hline Formal & Informal \\
\hline & Culture \\
Values \\
System of property rights & Behaviour patterns \\
Statutory law, normative law & $\begin{array}{c}\text { Religion and beliefs } \\
\text { Social trust }\end{array}$ \\
Public, social, financial regulations & $\begin{array}{c}\text { Mental models - methods of reasoning } \\
\text { and thinking which dominate in } \\
\text { particular societies }\end{array}$ \\
\hline
\end{tabular}

Economists representing the new institutional stream emphasize the fact that formal institutions may be quickly modified in response to the dynamically changing external environment, whereas informal institutions, which are deeply rooted in history, geography or religion of a particular country, undergo changes very slowly [Miłaszewicz, 2011, pp. 6-7]. At present, in large, complex communities, it is impossible to function only on the basis of informal institutions, as it used to be at the dawn of history. The complexity, number and variety of different interactions force individuals and organisations to function on the basis of numerous formal institutions 
that provide regulations of our everyday social and economic life. Both types of institutions cannot function independently of each other. They must complement each other, and they must be in compliance with each other. As a result, in a properly functioning state, we can observe institutional balance [Rudolf, W., 2015, pp. 114-115]. The lack of balance may result in the downfall of all systems, and the most spectacular example is the fall of the socialist system [Rudolf, S., 2015, p. 25].

Formal and informal institutions are complementary, which means that the lack or improper functioning of one institution is compensated by another one. One of the scientists who analysed informal institutions in the Western Balkan Mountain region (in post-socialist countries) defines such coexistence as the acceptable game principles in the society, depending on the quality of provided services. At places where state institutions fail, shortcomings are compensated by informal institutions, within the meaning of the grey market [Marcic, 2015, pp. 1-14]. In the countries where some profound changes have been taking place, as it can be observed in post-socialist countries, the acceptance of new game principles (in this case, market economy) may encounter some problems, as it once happened in Poland.

Thoughtless implementation of solutions that have proved to be efficient in some other societies often leads to serious institutional tension and dissonance between formal and informal institutions [Gruszewska, 2017, p. 44]. All players (individuals and organisations) expect that formal institutions will provide conditions that are favourable for broadly understood activities through the development of transparent and simple principles, in order to define the rules for such activities. The more efficient the network of formal institutions is, the more trust towards public institutions can be observed. Efficient organisation of formal institutions comes as a barrier to corruption, greed and excessive bureaucracy. It also reinforces such entrepreneurs' attitudes as, for example, business trust [Rudzewicz, 2016, p. 210]. In a situation where the above-mentioned dissonance can be observed, general trust and trust towards state institutions is decreased, and it directly affects business activities in a particular country [Gruszewska, 2017, p. 44].

The notion of trust, its place in new institutional economics and its significance for innovation in economy

The dynamic and complex institutional, technological and organisational reality in which individuals function results practically in a constant sense of uncertainty. There is even a special term to define a human being who lives under the constant sense of threat: Homo timidus. In such circumstances, trust acquires some special significance, which enables people to function in the contemporary world [Krot, Lewicka, 2016, p.17]. The notion of trust is very difficult to be defined precisely. Moreover, definitions that have been developed in various fields of knowledge present it from the points of view that are accepted within those scientific fields. Table 2 presents various definitions of trust.

Table 2. Trust

\begin{tabular}{|c|c|c|}
\hline \multicolumn{3}{|l|}{ Trust } \\
\hline Author & Field of science & Definition \\
\hline R. Harding & Political science & $\begin{array}{l}\text { Faith that other people have sincere intentions towards the trusting person, along } \\
\text { with competences to implement what is expected from them. Intentions may result }\end{array}$ \\
\hline
\end{tabular}




\begin{tabular}{|l|l|l|}
\hline & & $\begin{array}{l}\text { from three sources: (1) morality; (2) features of character; (3) benefits from the on- } \\
\text { going relationship }\end{array}$ \\
\hline P. Sztompka & Sociology & It is a bet taken on some uncertain future actions undertaken by other people \\
\hline F. Fukuyama & $\begin{array}{l}\text { Political philosophy, } \\
\text { economics, political science }\end{array}$ & $\begin{array}{l}\text { An assumption that other members of a community are honest and cooperating and } \\
\text { their behaviour is based on generally accepted standards }\end{array}$ \\
\hline E. Uslaner & Political science & It is a result of proper socialisation \\
\hline A. P. Robins, D. DeCenzo & Economics, management & Faith in other people's worthiness, character and capabilities \\
\hline
\end{tabular}

Considering the perspective of economic reality, market and the trade process, trust proves to have the most significance in the definition provided by Fukuyama. Therefore, our further analysis is based on that definition.

It is possible to analyse trust at three levels: the macro-level, the mezzo-level and the micro-level [Świeszczak, 2016, p. 115]. The macro-level generally refers to political and social environment, legal norms, and it is the most significant from the point of view represented by NIE, and more specifically, by the theory of transaction costs, the theory of agency and the theory of property rights. Trade occurs when profits exceed loss, and additionally there are some alternative trade partners. The choice of a trade partner (maybe a new one after the current ones have been abandoned) takes place as a result of the analysis of all the offers, and the partner who presents the best offer is selected. Considering benefits that result from trust, the macro-level refers to reduction of transaction costs, maintenance of the functioning of markets, development of cooperation networks, social cohesion and civil culture [Plichta, Plichta, 2013, p. 44].

The mezzo-level refers to cooperation of various groups and organisations that are focused on the implementation of some common objectives. Along with the macro-level, this level seems highly significant in providing favourable conditions to the development of economy and the growth of its innovation. At this level, trust significantly affects coordination within an organisation, and it improves its capabilities to survive crises [Plichta, Plichta, 2013, p. 44]. The micro-level can be defined as everyday establishment and maintenance of personal relations, indispensable for establishment and operation of an organisation. At this point, the abovementioned innovation in the context of trust should be also referred to, however in the micro-scale. People who trust other people take up risk more willingly, because they seem to consider any possible failures of innovative ideas as less severe. Such people expect to receive social support more than to be taunted by those who have witnessed their failure. They tend to do so because they believe that assuming good human nature is much better than extending their distrust onto the whole population and suspecting possible mischievous intentions [Skarżyńska, 2007, p. 66].

It is possible to indicate various types of trust:

- Personal trust (towards particular people such as family members, friends, acquaintance, neighbours);

- Positional trust (towards social roles or offices, e.g. physicians, lawyers, soldiers);

- Commercial trust (towards particular brands, goods or services);

- Technological trust (towards particular ITC systems);

- Institutional trust (towards hospitals, banks, higher education institutions) [Sztompka, 2002, pp.104-11]

Trust and other values that are important in a particular society (hence informal institutions, according to NIE) develop social capital, and its measure refers to people's ability for bottom-up self-organisation and their 
civil commitment, along with altruism, honesty and participation in charity actions. Francis Fukuyama indicates that high social capital is a domain of stable societies with well-established, durable political and legal systems. In his opinion, following common standards and values underlies the development of trust, and subsequently, it fosters efficiency in the functioning of groups or institutions [Sierocińska, 2011, p. 70]. The notions of social capital and trust become particularly significant in the field of innovation, because here it is possible to discuss cooperation of two or more entities that are related to an undertaking the success of which is not guaranteed. Making risky investment decisions and subsequent faster accepting newly implemented products and technologies are typical of countries that indicate low uncertainty avoidance, according to the typology provided by Geert Hofstede [Hofstede, 2011, p. 214]. Also, in such countries more people take the risk related to self-employment, and according to Joseph Schumpeter, who is referred to in Geert Hofstede's book, the main sources of innovation in a society are entrepreneurs. Summing up, countries indicating low uncertainty avoidance (showing more confidence) are more innovative [Hofstede, 2011, p. 2019].

Table 3. The uncertainty avoidance rate (of the Scandinavian countries, according to Hofstede*

\begin{tabular}{|c|c|}
\hline \multicolumn{2}{|c|}{ Uncertainty avoidance, according to Hofstede } \\
\hline Denmark & 23 \\
\hline Finland & 59 \\
\hline Island & 50 \\
\hline Norway & 50 \\
\hline Sweden & 29 \\
\hline
\end{tabular}

* On the scale, the 0 value means the lowest uncertainty avoidance (the highest confidence), the rate of 100 indicates the highest uncertainty avoidance (the lowest confidence).

Source: the Authors' own work based on: https://www.hofstede-insights.com, accessed on: 15th April 2018

It means that (see Table 3) among the Scandinavian nations, the most trusting people who are willing to take up the highest risk and who are most open to innovation are the Danes and the Swedish. Other countries take their positions at the half of the scale, approximately.

\section{$4 \quad$ Innovation in the Scandinavian countries}

Stable societies, where it is possible to face predictable situations and where actions are based on established and, which is even more important, respected legal, social and moral regulations, are characterised by a high level of trust [Mularska-Kucharek, 2011, p. 78]. The high level of trust provides proper environment for creation and later development of innovation. Innovation is implementation of new or significantly improved products (or services), new or significantly improved processes, new marketing methods or new methods of organising business practice, workplaces or relations with the external environment [Kisielnicki, 2016, p. 69]. Nowadays, development of competitive advantage is possible only by focusing on innovation, not only at the level of particular entities operating in economy (organisations), but also by developing the culture of innovation in the society. It was manifested by the European Union in 2000 when the Lisbon Strategy 2000-2010 was accepted. As its continuation, the Strategy Europe 2010--2020, emphasizes the significance of the development of European economy based on knowledge. It also emphasizes the significance of research and development and innovation activities [Limański, 2011, p. 140]. According to the World Bank, economy based on knowledge (knowledge economy [KE]) involves common application of advanced technologies, the development and practical use of 
which high qualifications are required [Zorska, 2012, p. 32], which is, namely, the above-mentioned social capital. The World Bank indicates four pillars of KE:

(1) The system of economic stimuli and the institutional framework: business environment, favourable conditions provided by the state for the development of entrepreneurship and innovation and for taking risk;

(2) Education and training - providing highly qualified staff; on one hand, it supports local innovation and on the other hand, it may attract foreign investors;

(3) Information infrastructure - development and maintenance of telecommunication and ICT networks;

(4) The national system of innovation - a national programme dedicated to provide support to the diffusion of innovative solutions among various entities in other sectors or regions; it is run and funded by the state [Zorska, 2012, p. 33].

The economies of the Scandinavian countries are among the most competitive economies in the world, and their competitiveness is measured in several fields: macro-economic stability of the state affected by public finance, inflation and the condition of the legal system. Additionally, an important role is performed by quality of education, a high level of technological advancement and high quality of the operation of state institutions [Leśniewski, 2015, p. 15]. It can be observed explicitly in their allocation of GDP, which is dedicated to research in comparison to other countries of Western Europe. Considering expenditures for research and development in 2014, the average of 27 EU countries was 2.17\% of the GDP, whereas in Finland it was 3.55\%, in Sweden 3.41\%, and in Denmark 2.98\%. Norway was the only country where that rate was lower than the average, namely $1.65 \%$ of the GDP; however, it should be remembered that because of Norwegian oil and gas deposits, the GDP of Norway results in the fact that if the Norwegian expenditure was calculated per capita, the obtained figure would place Norway on the top position of the ranking [https://www.spcc.pl/node/17412, accessed on 3rd May 2018]. Provided by UNESCO, the latest data of 2017 confirm the orientation towards development through research and innovation: Finland $-3.2 \%$, Sweden $-3.1 \%$, Denmark $-3 \%$, and Norway $-1.7 \%$. For comparison, last year Poland assigned only $0.9 \%$ of its GDP for research and development [http://uis.unesco.org/apps/visualisations/research-and-development-spending/ accessed on 3rd May 2018].

The above-mentioned national systems of innovation function in various ways in the particular Scandinavian countries, however, it is possible to state that they do so in an equally efficient way in each of these countries.

The Swedish advancement along the path of innovation was accompanied by a decrease in the dynamics of the economic growth in the 1970s, growing costs related to the maintenance of the welfare state in the 1980s and, eventually, the recession of the 1990s [Rudolf, 1996, pp. 275-276]. As a result, in 2001, VINNOVA, Sweden's Innovation Agency, was established as a body of high autonomy, with a vast budget. Its operations have been focused on the fields that directly respond to the needs of economy and provide solutions to the current problems. Continuing its model of innovation implementation, Sweden has based it on the guidelines provided by the OECD, which recommend solutions applied in the Finnish economy [Szmigiel, 2014, p. 116]. The above-mentioned Finnish experience includes abandonment of current intervention into economy, operation of domestic companies on the domestic market and orientation towards operations of strategical nature, which allow Finnish companies to compete or event to become leaders on the global markets. The above-mentioned strategical operations have been focused on two fields, namely, education and the national system of innovation where three institutions take a very special position: the Academy of Finland, the National Technology Agency TEKES and the Finnish 
Innovation Fund for Research and Development SITRA. The first two entities are responsible for the indication of the main lines for operations undertaken in the field of research and development, and the third entity is responsible for funding that have been recommended [Zorska, 2012, 50]. The origin of the Danish system of innovation is similar to the Finnish one. In the 1950s, Danish economy was largely based on agriculture, however, the global tendencies in economy and the economic conditions in the country resulted in a change in the strategy of the state, orienting it towards innovation and competitiveness. DASTI (Danish Agency for Science Technology and Innovation) performs a very important role in the architecture of the national system of innovation in Denmark. It does not operate autonomously, but it cooperates closely with the government and its developmental strategy [Senger, Mroczkowski, 2016, p.16]. The main institution in the Norwegian system of innovation is Innovation Norway, whose most important tasks are focused on the development of competitiveness, promotion of Norwegian companies in the domestic and international markets, transformation of ideas into successful business enterprises and promotion of cooperation among business, knowledge centres and research and development institutions [https://www.innovasjonnorge.no/en/start-page accessed on 3rd May 2018].

\section{$5 \quad$ Analysis of trust and innovation in the Scandinavian countries}

Innovativeness of particular countries is measured on a regional scale, e.g. the European Innovation Scoreboard, as well as in the global scale, the Global Innovation Index. In both rankings mentioned above, the Scandinavian countries take the top positions. In the research study provided by the European Innovation Scoreboard in 2017, Sweden took the second position after the leader, Switzerland, and the other Scandinavian countries, Denmark, Finland, Iceland and Norway occupied respectively the third, the fourth, the eighth and the twelfth positions. The fact that the countries of Northern Europe are the leaders in their continent does not come as a big surprise, whereas the fact that they are leaders in the global rankings, where they do better than some Asian economic tycoons, is very interesting. Table 4 presents a list of the positions they take, and Figure 1 presents some trends which can be observed in relation to the summary list of the rankings of the last few years.

Table 4. The ranking of the Scandinavian countries by the innovation rate

\begin{tabular}{|c|c|c|c|c|}
\hline & \multicolumn{4}{|c|}{ Country } \\
\hline & Denmark & Finland & Norway & Sweden \\
\hline 2013 & 9 & 6 & 16 & 2 \\
\hline 2014 & 8 & 4 & 14 & 3 \\
\hline 2015 & 10 & 6 & 20 & 3 \\
\hline 2016 & 8 & 5 & 22 & 2 \\
\hline 2017 & 6 & 8 & 19 & 2 \\
\hline
\end{tabular}

Source: Authors' own study based on: https://www.globalinnovationindex.org, accessed on 22 April 2018 


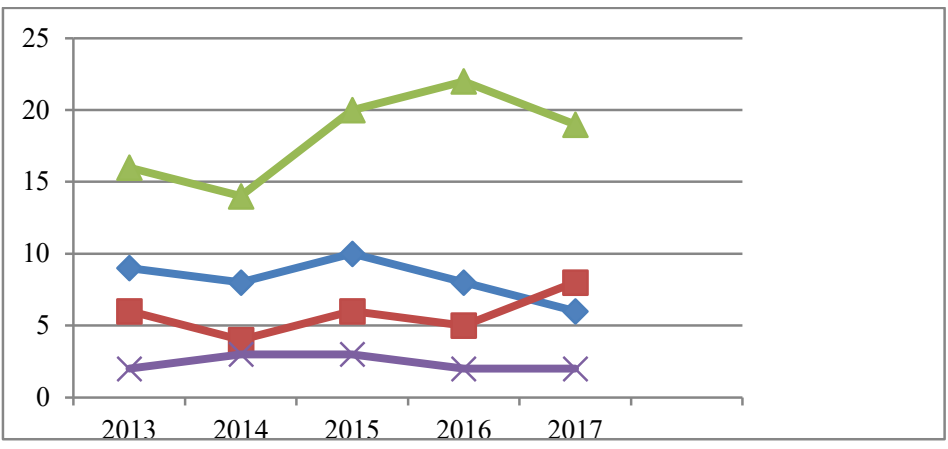

Figure 1 Changes in the positions taken by the Scandinavian countries in the innovation ranking (Denmark blue, Finland red) Source: Authors' own study based on: https://www.globalinnovationindex.org, accessed on 22 April 2018

As it can be observed, the most stable situation prevails in Sweden, which is placed in the second position in the ranking, falling by one position for two years. In 2017, Finland, which in 2014 was just behind Sweden, reported the weakest results during the analysed time period, and it fell significantly by several positions. An opposite situation can be observed for Denmark, which in 2015 reported its lowest position, but since then it has been following a growing trend. As the data indicate, this country wins higher positions in the ranking every year.

The diagram indicates quite remarkable consistency of Iceland in taking the 13th position (four times), with one year when a decrease was reported, resulting in the 19th position in the ranking. Norway takes the lowest position in the ranking of all the Scandinavian countries. Its highest position was the 14th place, and such a low position has never been reported for Denmark, Sweden or Finland.

For comparison, starting from 2013, Poland took respectively the 49th, 45th, 46th, 39th and 38th positions in the ranking. The Scandinavian countries took their positions in the top 10 of the group of 40 countries reported in the Global Cleantech Innovation Index 2017, which was developed by the World Wide Fund for Nature (WWF) and the Cleantech Group. In the survey, it is indicated which countries show the highest likelihood of establishment and development of companies and solutions in the field of clean technologies. The leader of the ranking is Denmark (the first position), followed by Finland and Sweden. Norway has won the 9th position and Poland, for comparison, has taken the distant 24th position [https://www.spcc.pl/node/20057, accessed on 22nd April 2018]. Four Scandinavian countries that are discussed here have been taking the first four positions in the World Values Survey unchangeably since the 1980s. Furthermore, over the last few years, the analysed confidence indicator in the surveyed countries has been successively growing, as it can be observed in Table 5 and Figure 2 .

Table 5. The confidence indicator in the Scandinavian countries

\begin{tabular}{|l|c|c|c|c|}
\hline & $\begin{array}{c}\text { The } \\
\text { beginning of } \\
\text { the 1980s }\end{array}$ & $\begin{array}{c}\text { The } \\
\text { beginning of } \\
\text { the 1990s }\end{array}$ & 2008-2009 & Average \\
\hline 1. Norway & 61,2 & 65,1 & 75,1 & 67,13 \\
\hline 2. Sweden & 57,1 & 66,1 & 70,7 & 64,63 \\
\hline 3. Denmark & 56 & 57,7 & 76 & 63,23 \\
\hline 4. Finland & 57,2 & 62,8 & 64,7 & 61,57 \\
\hline
\end{tabular}




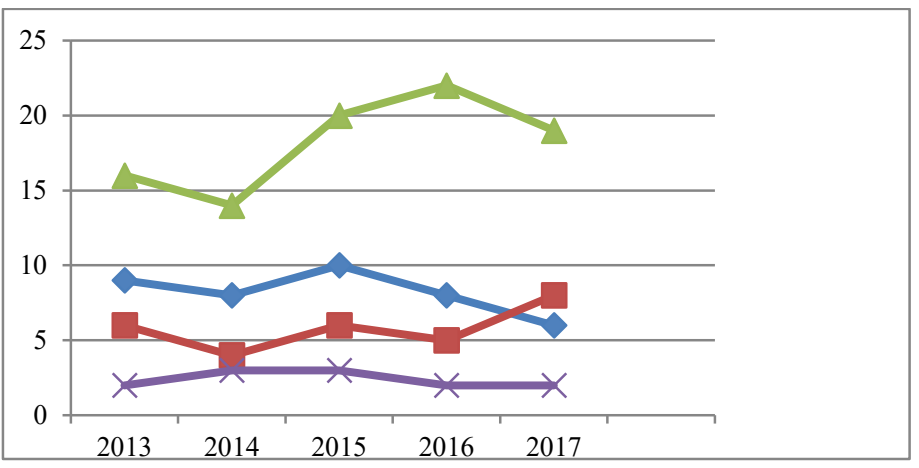

Figure 2. Changes in the confidence indicator in the Scandinavian countries (Denmark red, Finland red) Source: Authors' own study based on: [Svendsen, 2015, pp. 95-97]

The analysis indicates that all the discussed countries have been consistently taking top positions for over 30 years; moreover, they have been maintaining growth characteristics with regard to the analysed value. The highest growth during the analysed time period has been reported by Denmark (almost 20\%), and subsequently, a slightly lower level of growth has been reported by Norway (approximately 14\%) and by Sweden (approximately 13\%). The least impressive results have been reported by Finland (however, it still takes the fourth top position in the world) - approximately 7\%. While providing a comparative analysis of both rankings, it is possible to observe that considering the confidence indicator reported by the Scandinavian countries the leading country in this group is Norway, which has received the lowest score for innovation at the same time. Sweden takes the second position in both rankings. An interesting observation can be made for two other countries: Finland and Denmark.

Reporting the lowest confidence indicator among the analysed countries, Finland outdoes "more confident" Denmark in the ranking of innovation. Here, it would be worth referring to the list presented by Svendsen to find Switzerland in it, which has been an unquestionable innovation leader for many years. The survey on trust carried out in that country has eventually placed it on the 8th position of that global ranking, with an average at the level of 47.7 [Svendsen, 2015, pp. 95-97] .

All the discussed countries have been unchangeably maintaining high levels of their innovation, with some periodical variations. During the analysed time period, no explicit and constant downward or upward trends can be observed. Viewed from the perspective of the research, a slightly decreasing confidence indicator in these economies seems interesting, along with the factors that have caused such a decrease in the discussed rate in all the analysed countries.

\section{Conclusion}

The level of trust in a particular society comes as one of the factors supporting innovation in a particular country, however, it is not a sufficient condition. If it were the case, Norway would outdo other Scandinavian countries, and it would also outmatch the current world leader, Switzerland. Undoubtedly, the high level of trust reported by the Scandinavian countries comes as a factor which for many decades has facilitated the design and maintenance of the efficient functioning of the welfare states, where the structure of the economic systems is based on very high taxes [Svendsen, 2015, 90-99]. Based on the presented review, it is highly possible to state that in the Scandinavian countries, to a larger extent, formal institutions rather than informal ones significantly influence the 
high level of innovation through investment into research and development activities, the structure of the national systems of innovation, perfect local infrastructure and good education of citizens in those countries.

The conclusions drawn from this research can be important for organisers of economic life in the countries reporting lower levels of innovation than the analysed Scandinavian countries. One of the conditions that is required for an increase in the innovation rate and the competitiveness of economies in the global market is undoubtedly providing properly oriented education for people who will later on work for and contribute to the most innovative economic sectors. Another condition is providing opportunities for activities that are characterised by a high level of innovation (through operations undertaken by other formal institutions of particular countries).

In the context of the aim of the considerations presented above, it is possible to assume that formal and informal institutions are of key importance in providing favourable conditions for innovation in economy. Trust among entities of that system is important, however, understanding its significance requires some further in-depth scientific research. The analysis of the structure of the (innovation and trust) indicators applied in the research on the discussed phenomenon could provide cognitively interesting conclusions, which, however, go beyond the framework of this article.

\section{References:}

Chotkowski, J., (2010), Instytucje rynkowe $i$ koszty transakcyjne kluczowe pojęcia nowej ekonomii instytucjonalnej, Roczniki Nauk Rolniczych, Seria G, t. 97, z. 2

Czajkowska, M., (2008), Kultura zaufania w organizacji, Etyka w życiu gospodarczym, vol. 11, nr 1.

Fiedor, B., (2015) Instytucje formalne i nieformalne w ksztaltowaniu trwatego rozwoju, „Studia i prace wydziału nauk ekonomicznych i zarządzania" nr 40, t. 2, Wydawnictwo Uniwersytetu Wrocławskiego, Wrocław

Gruszewska, E., (2017), Instytucje formalne i nieformalne. Skutki antynomii, „Prace Naukowe Uniwersytetu Ekonomicznego we Wrocławiu", nr 493.

Hofstede, G., Hofstede G. J., Minkov M., (2011), Kultury i organizacje, Polskie Wydawnictwo Ekonomiczne, Warszawa.

Kisielnicki, J., (2016), Innowacyjność gospodarki polskiej na tle wybranych krajów Unii Europejskiej i świata, „Studia Ekonomiczne. Zeszyty Naukowe Uniwersytetu Ekonomicznego w Katowicach”, nr 281

Krot, K., Lewicka, D., (2016) Zaufanie w organizacji innowacyjnej, Wydawnictwo C.H.Beck, Warszawa

North D.C., (1991), Institutions, „Journal of Economic Perspectives”, No 5. za: Kuder, D., (2011), Pojęcie instytucji w teorii ekonomii, w: Nierówności Spoleczne a wzrost gospodarczy, Zeszyt 19, Uniwersytet Rzeszowski, Katedra Teorii Ekonomii i Stosunków Międzynarodowych, Rzeszów, 2011

Leśniewski, L., (2015), Gospodarki Danii, Finlandii i Szwecji a globalny kryzys finansowy, „Ekonomia Międzynarodowa" nr 9

Limański, A, (2011), Rola innowacyjności w budowaniu przewagi konkurencyjnej przedsiębiorstwa w gospodarce opartej na wiedzy, „Nierówności Społeczne a Wzrost Gospodarczy”, nr 23

Marcic, S., (2015), Informal Institutions in the Western Balkans: An Obstacle to Democratic Consolidation, "Journal of Balkan and Near Eastern Studies", nr 1(17)

Miłaszewicz, D., (2011) Jakość instytucji a wzrost gospodarczy, Zeszyty Naukowe Uniwersytetu Szczecińskiego. „Studia i Prace Wydziału Nauk Ekonomicznych i Zarządzania”, nr 19

Mularska-Kucharek, M., (2011), Zaufanie jako fundament życia społecznego na przykładzie badań w województwie łódzkim, ,Studia Regionalne i Lokalne” nr 2(44)/2011

Paliszkiewicz, J., O., (2010) Zaufanie a wyniki działalności przedsiębiorstwa - przeglad literatury, Zeszyty naukowe SGGW, „Ekonomika i Organizacja Gospodarki Żywności”, nr 82

Rudolf, S., (1996) Kontrowersje wokót państwa opiekuńczego na przykładzie Szwecji, w: Socjalne aspekty społecznej gospodarki rynkowej, materiały konferencyjne, Wisła, 3-5 czerwca 1996, red. E. OkońHorodyńska, Akademia Ekonomiczna im. Karola Adamieckiego, Katowice 1996, s. 275-276, za: Szmigiel, K., (2014), Wplyw uwarunkowań spoleczno-gospodarczych na ewolucje polityki innowacyjnej w Szwecji, „,Studia Ekonomiczne", tom166.

Rudolf, S.,(2015), Budowa równowagi instytucjonalnej na poziomie ponadnarodowym na przykładzie instytucji partycypacji pracowniczej, „Prace naukowe Uniwersytetu Ekonomicznego we Wrocławiu”, nr 405 
Rudolf, W., (2015), Możliwości wykorzystania nowej ekonomii instytucjonalnej w rozwoju sektora publicznego, „Zarządzanie publiczne”, 2(30)

Rudzewicz, A., (2016), Zaufanie społeczne $w$ otoczeniu przedsiębiorstwa, Zarządzanie i Finanse „Journal of Management and Finance" Vol. 14, No. 3/2/2016

Senger, K., Mroczkowski, K., (2016), Ekspertyza dla PARP: Funkcjonowanie Narodowych Systemów Innowacji (NSI) w Danii, Wielkiej Brytanii i Finlandii oraz ocena możliwości wykorzystania ich doświadczeń w Polsce, www.parp.gov.pl, dostęp: 03.05.2018

Sierocińska, K., (2011), Kapital społeczny. Definiowanie, pomiar i typy. „Studia Ekonomiczne”, nr 1 (LXVIII) 2011

Skarżyńska, K., (2007) Szkoła, media, kapitał społeczny. Jak korzystanie z mediów różnicuje kapitat społeczny różnych środowisk szkolnych, „Przegląd Psychologiczny”, t. 50, nr 1

Svendsen, G.L.H., (2015), The Puzzle of the Scandinavian Welfare State and Social Trust, "Issues of Social Science", Vol. 3, No. 2 Van der Geer, J., Hanraads, J. A. J., \& Lupton, R. A. (2000). The art of writing a scientific article. Journal of Science Communication, 163, 51-59.

Szmigiel, K., (2014), Wpływ uwarunkowań społeczno-gospodarczych na ewolucje polityki innowacyjnej $w$ Szwecji, „Studia Ekonomiczne”, tom 166.

Sztompka P., (2002), Socjologia. Analiza społeczeństwa. Wydawnictwo Znak. Kraków, za: Krysztopik, M., Rudzewicz A., (2011) Rola zaufania w gospodarce, „Zeszyty Uniwersytetu Szczecińskiego”, nr 662, „Ekonomiczne Problemy Usług”, nr 74.

Świeszczak, M., (2016), Zaufanie do sektora bankowego, w: Etyka $w$ relacjach instytucji finansowych $z$ gospodarstwami domowymi, Wydawnictwo Uniwersytetu Łódzkiego, Łódź.

Woźniak-Jęchorek, B., (2014), J.R. Commons vs. O.E. Williamson - dwie szkoły instytucjonalne i ich dorobek z punktu widzenia ekonomiki rynku pracy, ,, Studia Prawno-Ekonomiczne”, tom XCII

Zorska, A., (2012), Narodowy system innowacyjności jako filar gospodarki opartej na wiedzy, „Kwartalnik Kolegium Ekonomiczno-Społecznego Studia i Prace", nr 2.

Zorska, A., (2012), Narodowy system innowacyjności jako filar gospodarki opartej na wiedzy, „, Kwartalnik Kolegium Ekonomiczno-Społecznego Studia i Prace", nr 2

\section{Internet sources:}

Global Innovation Index, https://www.globalinnovationindex.org, dostęp: 22.04.2018

Hofstede Insight, https://www.hofstede-insights.com, dostęp: 15.04.2018

https://www.parp.gov.pl/images/PARP_publications/pdf/2016_ekspertyza_nsi.pdf, dostęp: 03.05.2018

Scandinavian-Polish Chamber of Commerce (SPCC), Nordycki Rocznik Statystyczny 2014 - Nowe technologie oraz badania i rozwój $w$ krajach skandynawskich, https://www.spcc.pl/node/17412, dostęp: 01.05.2018

Scandinavian-Polish Chamber of Commerce (SPCC), Państwa skandynawskie prowadza w globalnym rankingu innowacji w branży czystych technologii, https://www.spcc.pl/node/20057, dostęp:22.04.2018

UNESCO, How much does your country invest on $R \& D$ ? http://uis.unesco.org/apps/visualisations/research-anddevelopment-spending/ dostęp: 01.05.2018 